\title{
STRATEGI KONFLIK KOGNITIF DAPAT MEREDUKSI BEBAN MISKONSEPSI MAHASISWA CALON GURU KIMIA PADA KONSEP IKATAN KIMIA
}

\author{
Napsin Palisoa \\ Program Studi Pendidikan Kimia, Fakultas Keguruan dan IImu Pendidikan \\ palisoanapsin@gmail.com
}

\begin{abstract}
The concept of chemical bonds is often understood in a misconception by some students which causes the understanding of misconceptions also occurs in advanced chemical concepts. The research objective is to reduce the misconception burden of chemistry teacher candidates on the basic concepts of chemistry using cognitive conflict strategies. Case study research using qualitative methods with 10 students as research subjects obtained through misconception detection tests using the three tier test method. Research data obtained using data triangulation (observation, documents, and interviews). The results obtained indicate that the cognitive conflict strategy has succeeded in changing the cognitive structure (schemata) of individual students, causing changes in the burden of high misconceptions to low and understanding misconceptions (MK) to know the concept (TK). Future studies can use cognitive conflict strategies on other chemical concepts with high or low misconceptions.
\end{abstract}

Keywords: Misconception, chemistry student teachers, cognitive conflict strategy.

\begin{abstract}
ABSTRAK
Konsep ikatan kimia sering dipahami secara miskonsepsi oleh sebagian mahasiswa yang menyebabkan pemahaman miskonsepsi juga terjadi pada konsep-konsep kimia lanjutan. Tujuan penelitian, yaitu mereduksi beban miskonsepsi mahasiswa calon guru kimia pada konsep-konsep dasar kimia menggunakan strategi konflik kognitif. Penelitian studi kasus menggunakan metode kualitatif dengan 10 mahasiswa sebagai subjek penelitian yang diperoleh melalui tes pendeteksi miskonsepsi menggunakan metode three tier tes. Data penelitian diperoleh menggunakan triangulasi data (observasi, dokumen, dan wawancara). Hasil penelitian yang diperoleh menunjukakan strategi konflik kognitif berhasil merubah struktur kognitif (skemata) mahasiswa secara individu, menyebabkan terjadi perubahan beban miskonsepsi tinggi menjadi rendah dan pemahaman miskonsepsi (MK) menjadi tahu konsep (TK). Penelitian selanjutnya dapat menggunakan strategi konflik kognitif pada konsep-konsep kimia yang lain dengan beban miskonsepsi tinggi maupun rendah.
\end{abstract}

Kata Kunci: Miskonsepsi, mahasiswa calon guru kimia, strategi konflik kognitif.

\section{PENDAHULUAN}

Ilmu kimia umumnya memiliki konsep-konsep yang abstrak dan berjenjang, sehingga jika konsep-konsep dasar kimia dipahami secara abstrak yang menyebabkan pemahaman yang miskonsepsi, maka sangat dimungkinkan pemahaman konsep-konsep kimia lanjutan juga miskonsepsi. Faktor penyebab miskonsepsi pada siswa maupun mahasiswa, yaitu faktor internal (gaya belajar, model mental, dan konflik kognitif) dan eksternal (lingkungan, bahan ajar, dan guru). Salah satu faktor penyebab miskonsepsi yang sering terjadi pada siswa, adalah guru. Pernyataan tersebut dibuktikan dengan beberapa hasil penelitian sebelumnya, yaitu hasil penelitian Sheehan et al. (2012) menyatakan bahwa guru sains mengalami kesulitan menjawab pertanyaan dasar yang seharusnya sudah dikuasai. Lebih lanjut dijelaskan jika guru sains mengalami kesulitan dalam menjawab pertanyaan-pertanyaan dasar, maka dimungkinkan konsep sains yang diajarkan kepada siswa masih miskonsepsi. Hasil penelitian Unal et al. (2010) menunjukkan bahwa miskonsepsi siswa pada konsep ikatan kovalen bertambah setelah melakukan belajar di kelas. Hasil penelitian Kolomuc and Tekin (2011) menjelaskan guru memiliki miskonsepsi tentang konsep laju reaksi. 
Berdasarkan hasil penelitian di atas, dapat dijelaskan bahwa ketika guru masih mengalami miskonsepsi, maka pada saat mengajar dimungkinkan guru mentransfer pengetahuan yang miskonsepsi. Hasil penelitian tersebut diperkuat dengan hasil penelitian Lemma (2013), menemukan adanya korelasi yang signifikan antara intensitas miskonsepsi kimia pada siswa dan gurunya dengan nilai indeks determinasi $90 \%$. Hasil tersebut menunjukkan miskonsepsi yang terjadi pada siswa $90 \%$ disebabkan oleh faktor miskonsepsi yang terjadi pada guru, sedangkan $10 \%$ adalah akibat faktor lain. Bebarapa hasil penelitian tersebut menujukkan bahwa miskonsepsi yang terjadi pada siswa lebih besar dipengaruhi oleh guru dan faktor lainya, yaitu buku, bahan ajar, dan lingkungan.

Lembaga Pendidik dan Tenaga Kependidikan (LPTK) khususnya program studi pendidikan kimia sebagai lembaga penghasil guru, memiliki tanggung jawab dalam mempersiapkan calon guru kimia yang tidak membawa beban miskonsepsi ketika di sekolah nanti. Permasalahan yang dihadapi saat ini, yaitu bagaimana mahasiswa calon guru kimia dapat menyelesaiksan suatu masalah dengan benar, jika informasi maupun konsep yang dipahami dan telah tersimpan dalam memori jangka panjang adalah konsep yang miskonsepsi. Kondisi ini juga terjadi pada konsep ikatan kimia yang dipahami masih miskonsepsi. Dengan demikian, konsep ikatan kimia perlu diperbaiki, karena jika konsep ikatan kimia masih dipahami miskonsepsi, maka mahasiswa kesulitan dalam memahami konsep-konsep selanjutnya, karena konsep ikatan kimia merupakan konsep dasar bagi konsep-konsep selanjunya.

Keadaan tersebut tidak boleh biarkan karena mahasiswa tersebut pada saatnya menjadi calon guru kimia di sekolah. Peneliti sebagai salah satu tenaga pendidik di perguruan tinggi, terpanggil untuk campur tangan dalam mengatasi persoalan tersebut, membangun sebuah upaya untuk mereduksi beban miskonsepsi tinggi pada mahasiswa, khususnya pada konsep ikatan kimia sangat diperlukan dengan menggunakan strategi pembelajaran yang baik. Strategi belajar dikatakan baik, jika dalam proses pembelajaran mengacu pada perilaku dan proses berpikir (Slavin, 2012).

Teori konstruktivis mendukung proses perbaikan menyatakan bahwa peserta didik (mahasiswa) secara pribadi menemukan dan menerapkan informasi kompleks, mengecek informasi baru dibandingkan dengan informasi lama dan memperbaiki informasi lama apabila tidak sesuai. Jika konsepsi atau informasi lama tidak sesuai, maka perlu diciptakan kondisi konflik kognitif, sehingga terjadi perubahan konsep (conceptual change) pada pamahaman yang masih miskonsepsi.

\section{METODE PENELITIAN}

Metode yang digunakan dalam penelitian ini, yaitu metode kualitatif. Creswell (2012) menjelaskan bahwa qualitative methods memiliki keterkaitan dengan triangulasi. Proses triangulasi dalam suatu penelitian kualitatif terdiri dari (1) triangulation of observer, yaitu proses penggabungan pandangan para pengamat untuk mendapatkan gambaran lebih baik, (2) triangulation of theory, yaitu proses menggabungkan beberapa teori yang perspektif dalam merencanakan penelitian atau menginterpretasikan data, dan (3) triangulation of date, yaitu proses menggabungkan beberapa data penalitian. Penelitian ini menggunakan triangulasi data, yaitu observasi, dokumen, dan wawancara, selanjutnya interprestasi data untuk mendapatkan hasil yang baik.

Subjek dalam penelitian ini adalah mahasiswa Program Studi Pendidikan Kimia Universitas Pattimura, yang dipilih menggunakan teknik purposive sampling. Mahasiswa yang dipilih adalah: (1) mahasiswa yang telah mengikuti tes pendeteksi miskonsepsi, (2) mahasiswa memiliki beban miskonsepsi tinggi. Mahasiswa yang dipilih melalui tes diagnosis menggunakan metode three-tier diagnostic test untuk mendeteksi miskonsepsi mahasiswa. Three-tier diagnostic test dikembangkan untuk mengidentifikasi miskonsepsi siswa maupun mahasiswa (Eryilmaz dan Surmeli, 2002). Kriteria pengelompokan mahasiswa tergolong pada tahu konsep (TK), tidak tahu konsep (TTK), dan miskonsepsi (MK) berdasarkan respon jawaban mahasiswa pada masing-masing tier terlihat pada Tabel 1. 
Tabel 1. Kriteria Pengelompokan Konsepsi Mahasiswa Berdasarkan Three-tier Diagnostic Test

\begin{tabular}{|c|c|c|c|c|}
\hline Tier1 & Tier2 & Tier3 & \multirow{2}{*}{ Kelompok Konsepsi } & \multirow{2}{*}{ Singkatan } \\
\hline Jawaban & Alasan & Keyakinan & & TK \\
\hline Benar & Benar & Yakin & Tahu konsep & TTK \\
\hline Benar & Benar & Tidak yakin & Tidak tahu konsep & TTK \\
\hline Benar & Salah & Tidak yakin & Tidak tahu konsep & TTK \\
\hline Salah & Benar & Tidak yakin & Tidak tahu konsep & TTK \\
\hline Salah & Salah & Tidak yakin & Tidak tahu konsep & MK1 \\
\hline Salah & Benar & Yakin & Miskonsepsi 1 & MK2 \\
\hline Benar & Salah & Yakin & Miskonsepsi 2 & MK3 \\
\hline Salah & Salah & Yakin & Miskonsepsi 3 & \\
\hline
\end{tabular}

Sumber: Arslan et al., (2012)

\section{HASIL PENELITIAN}

Proses untuk mengetahui terjadinya konflik kognitif, yaitu dengan diberikan beberapa pertanyaan untuk menggambarkan tingkat kecemasan terhadap konsepsi lama dengan konsep baru dan benar yang disepakati para ilmuwan. Data kualitatif diambil melalui observasi dan dokumen menggunakan worksheet, dan wawancara.

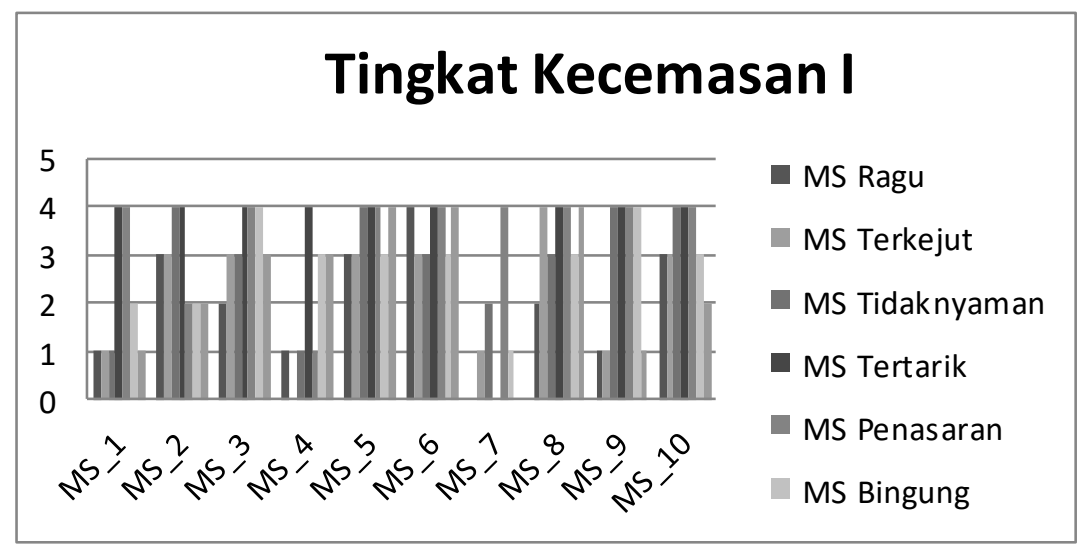

Gambar 1. Tingkat Kecemasan I Untuk Mengukur Konflik Kognitif

Gambar 1. menunjukkan mahasiswa mengalami konflik kognitif terhadap konsepsi yang dimiliki selama ini dengan konsep benar menurut para ilmuwan, ditunjukkan dengan tingkat kecemasan yang berbeda-beda pada tingkat keraguan, keterkejutan, dan ketidaknyamanan, ketertarikan, penasaran, kebingungan, dan kesedihan pada kategori rendah, sedang, dan tinggi. Proses tersebut menunjukkan mahasiswa telah berkonflik dengan konsep yang dimiliki sebelumnya dengan kategori yang berbeda. Dengan tingkat kecemasan tersebut, menunjukkan mahasiswa memiliki ketertarikan pada konsep baru.

Kondisi ini menyebabkan tingkat konflik kognitif pada kategori sedang, yang menunjukan mahasiswa cenderung masih mempertahankan konsep lama. Setelah melewati tingkat kecemasan pertama, dimana perubahan konsep belum terjadi secara keseluruhan, mahasiswa diberikan data dan penjelasannya, contoh-contoh tandingan dan analogi, untuk menyangkal konsep lama yang miskonsepsi dan masih dimiliki mahasiswa. Untuk merubah pemehaman miskonsepsi secara sempurna, maka tingkat kecemasan diukur pada tahap kedua. 


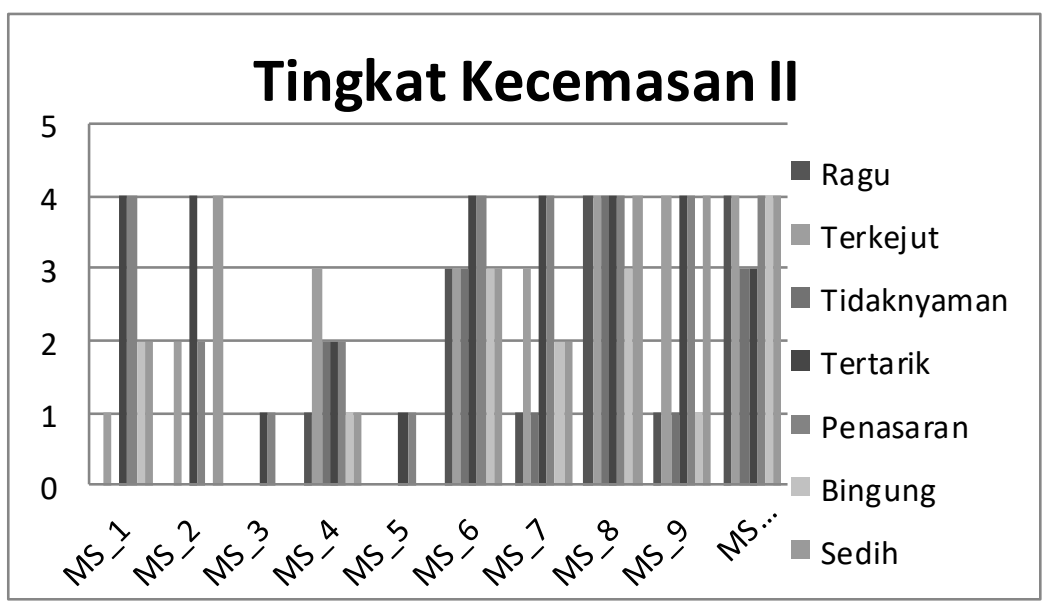

Gambar 2. Tingkat Kecemasan II Untuk Mengukur Konflik Kognitif

Gambar 2 menunjukkan proses konflik kognitif pada tingkat kecemasan kedua juga berbedabeda, namun kecenderungan tingkat kecemasannya tingi, bila dibandingkan pada tingkat kecemasan pertama. Hal ini menggabarkan terjadi perubahan konsep dari konsepsi yang salah (miskonsepsi) menjadi konsep yang benar. Kondisi ini didukung oleh jawaban mahasiswa yang sudah benar, sehingga dapat dikatakan bahwa pada tahap penciptaan konflik kognitif, mahasiswa telah mengalami proses akomodasi yang ditunjukkan dengan jawaban-jawaban yang diberikan telah benar.

Tingkat kecemasan mahasiswa juga ditunjukkan pada nilai tingkat kecemasan yang tinggi hamper semuanya berada antara 51\%-75\%. Ketika memperhatikan Gambar 1, dan menjawab pertanyaan pada pernyataan (a), mahasiswa menjawab tidak setuju. Artinya mahasiswa mulai memahami bahwa unsur-unsur pada golongan IA dan golongan IIA ketika membentuk senyawa dengan unsur-unsur pada golongan VIA dan golongan VIIA tidak semuanya membentuk atau tergolong ikatan ionik.

Mahasiswa lebih yakin lagi dengan pernyataan (b) mahasiswa menjawab tidak setuju dengan pernyataan pada (a). Artinya mahasiswa semakin memahami dengan penjelasan skala Pauling dan melihat Gambar 2 tentang nilai keelektronegatifan masing-masing unsur-unsur, bahwa unsur-unsur membentuk ikatan ionik jika nilai selisih elektronegatifitasnya lebih besar dari 1.7 (skala Pauling). Pada saat mengamati Gambar 1 dan 2 dan membaca pernyataan pada poin (a) dan (b), mahasiswa mulai berpikir dan mau merubah konsep lamanya dengan menerima konsep baru, yang ditunjukkan dengan memilih tidak setuju pada poin (a) dan (b). Hal ini menunjukkan terjadi bahwa proses akomodasi, yaitu menerima konsep baru dan merubah konsep lamanya yang tidak sesuai (Posner, 1982).

Proses di atas mendukung mahasiswa ketika menjawab pertanyaan (c) dan (d) dengan membuktikan skala Paulig, sehingga pada tingkat konflik mahasiswa ragu dan terkejut dengan definisi yang dibuat sebelumnya dan pemahamannya berbeda dengan para ilmuwan antara $51 \%$ $75 \%$, tingkat ketidaknyamanan, ketertarikan, dan penasaran antara $76 \%-100 \%$, tingkat kebingungan antara $51 \%-75 \%$, sedangkan tingkat kesedihannya karena dia belum memahami ikatan ionik antara $76 \%-100 \%$. Proses akomodasi juga terlihat atau nampak pada saat mahasiswa menjawab poin (c) dan (d) mahasiswa lebih mudah menentukan suatu senyawa ionik atau tidak dengan menggunakan skala Pauling.

Selain data observasi dan dokumen, hasil wawancara juga menunjukkan mahasiswa calon guru kimia pada tahap pertama penciptaan konflik kognitif, mahasiswa cenderung mempertahankan konsep awal yang diketahui masih miskonsepsi. Hal ini juga dipengaruhi oleh kondisi nyaman mahasiswa terhadap konsep lama, mahasiswa menganggap konsep lama yang 
dimilikinya adalah konsep yang benar. Mahasiswa belum menyadari pemahaman yang keliru, menyebabkan pemahaman miskonsepsi pada konsep ikatan kimia, hal ini juga mempengaruhi kesulitan mahasiswa pemahaman terhadap konsep-konsep lanjutan, yang memungkinkan terjadi miskonsepsi.

Pada tahap kedua dari konflik kognitif, tingkat kecemasan mahasiswa sudah tinggi, hal ini menunjukan bahwa mahasiswa memiliki konflik kognitif terhadap pemahaman awal dengan pemahaman baru menurut para ilmuawan. Pada kondisi ini mahasiswa telah menyadari bahwa, pemahaman tentang konsep ikatan kimia masih miskonsepsi sehingga konsep lama yang dimiliki harus dirubah dengan konsep baru menurut ilmuwan. Kondisi ini juga menunjukkan bahwa, struktur kognitif (skemata) mahasiswa tentang pemahaman konsep ikatan kimia yang miskonsepsi dapat berubah dengan pemahaman konsep yang benar.

\section{KESIMPULAN}

Tes pendeteksi miskonsepsi menggunakan metode three tier test, menunjukkan mahasiswa calon guru kimia Program Studi Pendidikan Kimia FKIP Unpatti memiliki beban miskonsepsi tinggi pada konsep ikatan. Beban miskonsepsi tinggi yang yang dimaksud, yaitu mahasiswa mengalami miskonsepsi lebih dari $50 \%$. Beban miskonsepsi tinggi harus direduksi menggunakan strategi konflik kognitif, dengan merubah struktur kognitif (skemata) mahasiswa yang miskonsepsi (MK) menjadi tahu konsep (TK). Strategi konflik kognitif menampilkan contoh-contoh tandingan, datadata konkrit dan analogi. Selanjutnya untuk mengetahui terjadi konflik kognitif pada mahasiswa, dapat dilihat pada jawaban terhadap pernyataan kecemasan yang diberikan. diukur dengan mahasiswa pertanyaan kecemasan. Semakin tinggi tingkat kecemasan mahasiswa, menyebabkan semakin tinggi konflik kognitif yang mengakibatkan semakin sepat perubahan miskonsepsi menjadi tahu konsep. Tingkat kecemasan mahasiswa dapat diukur beberapa tahap, sehingga kondisi konflik kognitif dan perubahan konsep dapat terjadi. Dalam penelitian ini, tingkat kecemasan diukur dua tahap, karena pada tahap pertama mahasiswa masih berada pada kondisi miskonsepsi, sehingga dilanjutkan pada tahap kedua, yang menyebabkan telah terjadi perubahan miskonsepsi (MK) menjadi tahu konsep (TK). Berdasarkan hasil yang diperoleh, melalui tahapan strategi konflik kognitif, miskonsepsi mahasiswa pada konsep ikatan kimia.

\section{DAFTAR PUSTAKA}

Al-Balushi, S. M., Ambusaidi, A. K., Al-Shuaili, A.H., Taylor, N (2012). "Omani twelfth grade students' most common misconceptions in chemistry". Internasional Council of Associations for Science Education. Vol.23, No.3, September 2012. Pp. 221-240.

Arslan, H.O., Cigdemoglu, C., and Moseley, C. (2012). "A Three-Tier Diagnostic Test to Assess Pre-Service Teachers' Misconceptions about Global Warming, Greenhouse Effect, Ozone Layer Depletion, and Acid Rain." International Journal of Science Education. Vol.34 No.11, pp.1667-1686.

Barke, H.D., Al Hazari, and Yitbarek, S. (2009). Misconceptions in Chemistry. Berlin: Springer Link.

Black, A.A., 2005, An Instrument for Testing Earth Science Misconceptions and Conceptual Difficulties: Development, Field Testing and Results, in preparation for publication.

Chakraborty, A. and Mondal, B.C. (2012). "Misconceptions in Chemistry At IX th Grade And Their Remedial Measures". Indian Streams Research Journal. Vol 2, Issue. 7, Aug 2012.pp.19.

Hans-Dieter, Barke Al Hazari, Yitbarek S. (2009). Misconception in Chemistry. Addressing Perception in Chemical Education Spinger-Verlagi Berlin Haidelberg. Universitas Munster Germany and University of Tennessee USA. 
Kolomuc, A., and Tekin, S. (2011). "Chemistry Teachers' Misconceptions Concerning Concept of Chemical Reaction Rate." Eurasian: Journal Physics and Chemistry Education. Vol.3 No.2, pp.84-101.

Lemma, Abayneh. (2013). A Diagnostic Asessment of Eighth Grade and Their Teacher' Misconseption about Basic Chemical Concepts. AUCE, 3(1), 39-59.

Pesman, H., and Eryilmaz, A. (2010). "Development of a Three-Tier Test to Assess Misconceptions about Simple Electric Circuits." The Journal of Educational Research. Vol. 103, pp.208222.

Posner, G. J., Strike, K. A., Hewson, P. W. (1982). Accommodation of a Scientific Conception: Toward a Theory of Conceptual Change. Departement of Education, Cornell University, Ithaca. New York.

Sheehan M., Peter E.C., Hayes S. (2014) The Chemical Misconceptions of Pre-service Science Teachers at the University of Limerick: Do they change. Departement of Chemical and Enviromental Science \& National Centre for Excellence in Mathematics and Science Teaching and Learning. University of Limerick. Ireland.

Unal S., Costu B., Ayas A. (2010). Secondary School Students' Misconception of Covalent Bonding. Journal of Turkish Science Education. 